\section{Long-term Effect of Manure Application in a Certified Organic Production System on Soil Physical and Chemical Parameters and Vegetable Yields}

\author{
Sven Verlinden ${ }^{1}$, Louis McDonald, James Kotcon, and Silas Childs
}

ADDITIONAL INDEX WORDs. tomato, green pepper, lettuce, zucchini, green bean, soil organic matter, soil bulk density, economics

SUMMARY. In 1999, West Virginia University (WVU) established an organic farming systems project with a market garden section consisting of 32 plots measuring $16 \times$ $25 \mathrm{ft}$ arranged in a completely randomized design. Sixteen of these plots were managed as high-input and 16 as low-input plots. High-input plots received 10 tons/acre per year of dairy manure and a rye-vetch (Secale cereale and Vicia villosa) cover crop during each winter season since the inception of the experiment in 1999. Fertility in low-input plots was managed solely with an annual rye-vetch cover crop while both treatments also received 5 tons/acre of mixed species hay used as mulch in 2 of every 4 years. A 4-year rotation of crops, green bean (Phaseolus vulgaris), zucchini (Cucurbita pepo), tomato (Solanum lycopersicum), green pepper (Capsicum annuиm), and lettuce (Lactuca sativa) in the Fabaceae, Cucurbitaceae, Solanaceae, and Asteraceae families, was established in 1999 and has been maintained ever since. Soil organic matter (SOM) in the upper 6 inches of the soil profile $(4.4 \%$ in 1999$)$ has remained unchanged in low-input plots at $5.2 \%$ in 2004 and $5.4 \%$ in 2014 , the year following transition and most recent data collection, respectively. During this same time period, significant increases in SOM from $6.4 \%$ in 2004 to $8.7 \%$ in 2014 were observed in high-input plots. Bulk density was lower in high-input plots than low-input plots in 2014. Despite these improvements in soil quality, high-input plots showed very high levels of phosphorus and potassium. Over the duration of the experiment, yearly manure application increased yields by $22 \%$ in all crops combined; however, individual crops responded quite differently. The yield was $9 \%$, $\mathbf{2 5} \%, \mathbf{2 4 \%}$, and $24 \%$ higher in high-input plots than in low-input plots for tomato, pepper, zucchini, and green bean, respectively. Manure application in addition to green manures and hay mulch incorporation was found to result in significant economic returns.

$\mathrm{T}$ he U.S. Department of Agriculture (USDA) defines organic production as "A production system that is managed in accordance with the Act (Organic Foods Production Act of 1990) and regulations ... to respond to site-specific conditions by integrating cultural, biological, and mechanical practices that foster cycling of resources, promote ecological balance, and conserve biodiversity" (USDA, 2002). In order for organic producers to accomplish this goal, many focus their production and

Division of Plant and Soil Sciences, West Virginia University, 3402 Agricultural Sciences Building, Morgantown, WV 26506-6018

This paper was part of the workshop "Soil Health and Implication in Organic Nutrient Management on Vegetable Production" held on 5 Aug. 2015 at the ASHS Annual Conference, New Orleans, LA, and sponsored by the Organic Horticulture Working Group.

${ }^{1}$ Corresponding author. E-mail: sven.verlinden@mail. wvu.edu.

doi: 10.21273/HORTTECH03348-16 management practices on soil physical, chemical, and biological properties including organic matter content, bulk density and tilth, microbial biomass, and nutrient levels. The number one production practice used by organic farms is the use of green or animal manures, and organic fertilizer purchases rank fifth in production expenses after feed, labor, supplies and repairs, and cash rent and lease
(USDA, 2015). Clearly managing soils and soil quality are a high priority in the organic production of crops.

Many of the changes that are envisioned in organic production can be slow to materialize since one major aim is long-term sustainability of the production system. Small incremental changes in a positive direction, especially in soil physical and chemical properties, are often key to implementation and maintenance of organic production systems. Both the 3 -year transition period and a mandate to build soils are therefore a basic requirement. Several long-term organic comparison trials in the United States attest to the need and usefulness of studies that go beyond traditional 2- to 4-year field studies (Delate et al., 2015; Idowu et al., 2009). Most of these long-term studies have been in agronomic crops (Delate et al., 2015). However, some efforts have been made to study long-term effects of organic management in vegetable production (Arthur et al., 2011; Idowu et al., 2009; Mitchell et al., 2007; Ozores-Hampton et al., 2012). Beyond these long-term studies, the effects of soil management on microbial biomass, weed pressure, nutritional content of the crop, and economics have been studied-to name a few (Chang et al., 2007; Darby et al., 2006, Gilman and Langer, 2011; Herenncia et al., 2011; Horneck, 1992; Schmutz et al., 2007; Srivastava et al., 2007). Despite these wide ranging topics, soil management seems to be at the basis of the many studies attempting to gauge long-term sustainability of organic production systems. Soil management can include tillage, compost and manure applications, cover crops and green manures, and crop rotations. In general, limiting tillage, judicious application

\begin{tabular}{llll}
\hline $\begin{array}{l}\text { Units } \\
\text { To convert U.S. to SI, } \\
\text { multiply by }\end{array}$ & U.S. unit & SI unit & $\begin{array}{l}\text { To convert SI to U.S., } \\
\text { multiply by }\end{array}$ \\
\hline 0.4047 & $\mathrm{acre}(\mathrm{s})$ & $\mathrm{ha}$ & $2.471 \mathrm{l}$ \\
0.3048 & $\mathrm{ft}$ & $\mathrm{m}$ & 3.2808 \\
2.54 & inch(es) & $\mathrm{cm}$ & 0.3937 \\
25.4 & inch $(\mathrm{es})$ & $\mathrm{mm}$ & 0.0394 \\
0.4536 & $\mathrm{lb}$ & $\mathrm{kg}$ & 2.2046 \\
48.8243 & $\mathrm{lb} / 1,000 \mathrm{ft}^{2}$ & $\mathrm{~kg} \cdot \mathrm{ha}^{-1}$ & 0.0205 \\
1.1209 & $\mathrm{lb} / \mathrm{acre}^{-1}$ & $\mathrm{~kg} \cdot \mathrm{ha}^{-1}$ & 0.8922 \\
0.0160 & $\mathrm{lb} / \mathrm{ft}^{3}$ & $\mathrm{~g} \cdot \mathrm{cm}^{-3}$ & 62.4274 \\
1 & $\mathrm{ppm}$ & $\mathrm{mg} \cdot \mathrm{kg}^{-1}$ & 1 \\
2.2417 & $\mathrm{ton}(\mathrm{s}) / \mathrm{acre}$ & $\mathrm{t} \cdot \mathrm{ha}^{-1}$ & 0.4461 \\
$\left({ }^{\circ} \mathrm{F}-32\right) \div 1.8$ & ${ }^{\circ} \mathrm{F}$ & ${ }^{\circ} \mathrm{C}$ & $\left({ }^{\circ} \mathrm{C} \times 1.8\right)+32$ \\
& & &
\end{tabular}


of compost and green manures, the use of cover crops and green manures, and crop rotations have all shown beneficial effects on a number of soil physical, biological, and chemical properties in vegetable production systems (Delate et al., 2008; Garcia et al., 2008; Gunter, 2010; Ndiaye et al., 2000; Pritchett et al., 2011; Swenson et al., 2004; Waldrip et al., 2012; Wu and Powell, 2007). These studies also allude to the complex interactions between physical, chemical, and biological properties that determine soil productivity.

The potential of soils to support plant growth is the result of both the inherent capacity to sustain crop production and the short- and long-term soil management practices, including tillage and the organic fertilizer applications used on that soil. The complex nature and combination of organic fertilizers together with their even more complex interaction with soils make organic soil management recommendations and decisions difficult (Lee, 2010). This is especially true when considering carry over effects from year to year and longer (Endelman et al., 2010). Soil health, soil potential, soil quality, and soil fertility-more or less defined in the literature-have all been employed to define the long-term carrying capacity of soil and sustainability of agroecosystems (Idowu et al., 2009; Knight et al., 2013). Despite the importance of soil, no one set of parameters has been unequivocally agreed on to measure these complex set of factors (Arthur et al., 2011; Idowu et al., 2009; Pattison et al., 2008).

In 1999 , to provide information on the long-term effects of different methods of organic production and soil management on soil health, soil quality, soil fertility, crop yields, weed pressure, disease and insect incidence, and economic returns the Division of Plant and Soil Sciences at WVU established a long-term organic farming systems project with agronomic, animal, and horticulture components. Two organic production systems were initiated. One was a crop-livestock experiment and the other a market garden experiment, data from which are reported here. Our overall goal was to compare the impact of long-term annual animal manure-based applications with green manures and the incorporation of hay mulches. Here we report data from two selected years (2004 and 2014), 1 year after transition (2000-03), and the last year for which we collected yields. Data on soil nutrient concentration, SOM, bulk density, yields, and economic returns immediately after the transition phase (2004) and 15 years (2014) into the project are presented as a means to quantify soil quality and long-term sustainability of the agroecosystems under study.

\section{Materials and methods}

General. The 63-acre WVU horticulture farm, located in Morgantown, WV, and managed conventionally for over 80 years, houses the long-term study described below. The farm, after an initial transition phase of 3 years, was certified organic in 2003 and has been operated under National Organic Program rules for the past 13 years. The market garden section of the farm consists of 2 acres of land with Tilsit (Typic Fragiudult) and Dormont (Ultic Hapludalf) series soils. These soils are silt loams of moderate natural fertility (USDA, 1982). The site is tile drained with a negligible slope. After initial tillage of grass sod in 1999, 32 plots measuring $16 \times 25 \mathrm{ft}$ were established in a completely randomized design. The experiment consisted of two organic production systems: one designated as high input and the other low input. Manure (10 tons/acre) was broadcast annually to the high-input treatment and the low received none. Both systems were assigned the same crops in a 4-year rotation. Within each of the four replications, four plots were assigned to a different crop at initiation, giving a total of 16 high-input and 16 low-input plots in a completely randomized design (Table 1). Cover crops and mulch were used in each system (Table 2 ). The manure used in our experiment consisted of dairy manure mixed with pine shavings, leaf litter, and tree trimmings. Manure analysis used in the high-input treatment is shown in Table 3. Fertility in low-input plots was managed solely with cover crop and mulch. Mixed species hay mulches used to control weeds in the Solanaceae and Cucurbitaceae plots (Years 3 and 4 of the rotation) were incorporated and short-term buckwheat (Fagopyrum esculentum) cover crops were established when land was fallowed for more than 6 weeks in both systems.
In general, plots were tilled three times per season, twice for initial seed bed preparation and weed control and a third tillage to establish a winter cover crop. When plots were fallowed, an additional fourth tillage was used to establish a short-season summer buckwheat cover crop. Data were collected on harvestable yield, soil fertility, and organic matter throughout the past 16 years in addition to sporadic measurements of other parameters. Here we present data on 2 years, 2004 and 2014, for which we have a complete set of data of all parameters.

SoIL FERTILITY. In Fall 2004 and 2014 , the upper 6 inches of the soil profile were sampled in each of the plots. Following air-drying, these samples were stored at room temperature. Soil analysis consisted of a Mehlich-1 extraction followed by nutrient concentration analysis. Soil analysis was carried out by the WVU Soil Testing Laboratory (Morgantown, WV).

SOM AND BULK DENSITY. The same soil samples used for nutrient analysis were used in a loss-on-ignition protocol to determine SOM content. Data are reported as percent SOM based on the weight of soil samples dried at $105{ }^{\circ} \mathrm{C}$, heated to $400{ }^{\circ} \mathrm{C}$ in a furnace and again after cooling. Bulk density sampling was carried out by pressing a metal ring with diameter 76.5 and $75.5 \mathrm{~mm}$ height into the soil profile, removing the soil core from the ring, drying the sample at $105{ }^{\circ} \mathrm{C}$, followed by weighing the soil core.

HARVESTABLE YIELD AND ECONOMICS. 'Provider' green bean, 'Dunja' summer squash, 'Ace' green pepper, and 'WV63' tomato were direct-sown or transplanted between 15 May and 15 June. Green bean was sown in rows $1 \mathrm{ft}$ apart at a rate of 1 seed/inch. Green bean was harvested three times starting early to mid-July in both 2004 and 2014 . Total harvestable yields of three harvests are reported. 'Dunja' summer squash was planted in two rows $5 \mathrm{ft}$ apart and thinned to one plant every 6 inches. Summer squash was harvested three times per week from late June to mid-August when most plants succumbed to squash vine borer (Melittia cucurbitae), squash bug (Anasa tristis), and powdery mildew (Erysiphe cichoracearum). Total harvestable yields of $\approx 20$ harvests throughout the season were reported. Tomato was planted in two rows $5 \mathrm{ft}$ apart with plants spaced 
at $2 \mathrm{ft}$ in a row. 'WV63' tomato was harvested once per week starting early August through late September. Harvestable yields on seven to eight harvests are reported. 'Ace' pepper was planted in rows $2 \mathrm{ft}$ apart and plants were spaced $1 \mathrm{ft}$ apart in the row. Green pepper was harvested about four times from mid-August to late September. All yields are reported in pounds per acre and prices used in economic analysis were based on prevailing local retail prices for organic vegetables. Lettuce yields - recorded as number of harvestable heads-are not reported here because of the inconsistent units used in data collection (number of heads vs. pounds). The price premium of using 10 tons/acre of manure was calculated by multiplying prevailing retail prices by the difference in weight of produce harvested from low- and high-input plots in 2014.

STATistics. All statistical analysis was performed with the statistical software package Sigmaplot 10 (Systat, San Jose, CA). Compost analysis is reported as the mean of 15 years of data followed by $\mathrm{SD}$ of the mean $(\mathrm{n}=15)$. The experiment was analyzed as a completely randomized design with two levels or treatments. Soil data were analyzed as a set of low-input $(\mathrm{n}=16)$ and a set of high-input $(\mathrm{n}=16)$ plots. $\mathrm{A}$ two-way (year and treatment) analysis of variance (ANOVA) was performed on individual nutrients and the means of each nutrient were separated by a Tukey's separation of means test. A two-way (treatment and year) ANOVA

Table 1. Crop variety and rotation in the long-term vegetable production systems experiment at the West Virginia University Organic Farm (Morgantown, WV).

\begin{tabular}{ll}
\hline Yr no. & \multicolumn{1}{c}{ Family: Variety and common name } \\
\hline 1 & Fabaceae: 'Provider' bean \\
2 & Asteraceae: 'Coastal Star' romaine lettuce \\
3 & Cucurbitaceae: 'Dunja' zucchini \\
4 & Solanaceae: 'WV 63' tomato and 'Ace' green pepper \\
\hline
\end{tabular}

was performed on the 2004 and 2014 yield data followed by an analysis of the combined and normalized yield data of the 2004 and 2014 season. Data were normalized to percent of average yield in each year of measurement because significant yield differences were observed between 2004 and 2014. Our analysis consisted of averaging the yield of the four low-input and four highinput plots of each crop and expressing individual plot data as percent of the mean of all plots. We in turn performed a one-way ANOVA on these normalized and combined data.

\section{Results and discussion}

SOM in all plots was $4.4 \%$ (top 6 inches) at the onset of our experiment in 1999. This relatively high SOM reflects the fact that the experimental area was in grass sod before our experiment was established. In agronomic crops conversion of sod to crop land showed similar high initial organic matter (Bowman and Anderson, 2002). After an initial increase of $0.8 \%$ from 1999 to 2003 , SOM has remained unchanged in low-input plots at $5.2 \%$ and $5.4 \%$ in 2004 and 2014, respectively (Fig. 1). Again,

Table 2. Cover crops and management of high- versus low-input plots in a 4-year vegetable rotation at the West Virginia University Organic Farm (Morgantown, WV).

\begin{tabular}{|c|c|c|}
\hline Treatment & High-input plots ${ }^{\mathrm{z}}$ & Low-input plots ${ }^{\mathrm{z}}$ \\
\hline \multicolumn{3}{|l|}{ Cover crop } \\
\hline $\begin{array}{l}\text { Hay mulch }(5 \text { tons/acre } \\
\text { incorporated at the end }\end{array}$ & $\begin{array}{l}\text { Year } 3 \text { and } 4 \text { of the crop rotation } \\
\quad \text { (Solanaceae and Cucurbitaceae) }\end{array}$ & $\begin{array}{l}\text { Year } 3 \text { and } 4 \text { of the crop rotation } \\
\text { (Solanaceae and Cucurbitaceae) }\end{array}$ \\
\hline
\end{tabular}

${ }^{{ }^{2}} 1$ ton $/$ acre $=2.2416 \mathrm{t} \cdot h a^{-1}, 1 \mathrm{lb} / \mathrm{acre}=1.1209 \mathrm{~kg} \cdot \mathrm{ha}^{-1}$.

Table 3. Analysis of the manure applied to high-input plots every year of the 15-year experiment. Nitrogen (N), phosphorus [P expressed as phosphate $\left(\mathrm{P}_{2} \mathrm{O}_{5}\right)$ ], potassium [K expressed as potash $\left(\mathrm{K}_{2} \mathrm{O}\right)$ ], copper $(\mathrm{Cu})$, calcium $(\mathrm{Ca})$, and magnesium $(\mathrm{Mg})$ are averages of 15 analyses over a period of 15 years. At the application rate of 10 tons/acre $\left(22.42 \mathrm{t} \cdot \mathrm{ha}^{-1}\right)$, this provides $\approx 3 \mathrm{lb} / 1000 \mathrm{ft}^{2}\left(146.48 \mathrm{~kg} \cdot \mathrm{ha}^{-1}\right)$ of which $35.7 \%$ is plant available when incorporated into soil according to the West Virginia Department of Agriculture laboratory that performed the analysis $(\mathbf{n}=15)$.

\begin{tabular}{|c|c|c|c|c|c|c|c|c|c|}
\hline \multicolumn{10}{|c|}{ Nutrients (\% dry matter) } \\
\hline & $\mathbf{N}(\mathrm{TKN})$ & $\mathrm{N}$ available & $\mathrm{N}$ ammonium & $\mathbf{P}\left(\mathbf{P}_{2} \mathrm{O}_{5}\right)^{\mathrm{z}}$ & $\mathbf{K}\left(\mathbf{K}_{2} \mathbf{O}\right)^{\mathrm{y}}$ & $\mathrm{Cu}$ & $\mathrm{Ca}$ & $\mathrm{Mg}$ & $\mathrm{pH}$ \\
\hline Ave & 0.66 & 0.21 & 0.05 & 0.60 & 0.68 & 0.0018 & 2.08 & 0.22 & 8.2 \\
\hline SD & 0.19 & 0.07 & 0.01 & 0.20 & 0.24 & 0.0006 & 0.19 & 0.07 & 0.5 \\
\hline
\end{tabular}

$\mathrm{TKN}=$ total Kjedahl $\mathrm{N}$.

${ }^{\mathrm{z}} \mathrm{l} \mathrm{mol} \mathrm{P}_{2} \mathrm{O}_{5}=0.4364 \mathrm{~mol} \mathrm{P}, \mathrm{l} \mathrm{mol} \mathrm{K} 2 \mathrm{O}=0.8301 \mathrm{~mol} \mathrm{~K}$. 
Table 4. Soil analysis of low-input plots (yearly incorporation of green manure and mulches) versus high-input plots [yearly incorporation of green manure and mulches and 10 tons/acre $\left(22.42 \mathrm{t} \cdot \mathrm{ha}^{-1}\right)$ of dairy manure] in 2004 and 2014.

\begin{tabular}{|c|c|c|c|c|c|}
\hline \multirow[b]{3}{*}{ Element } & \multicolumn{2}{|c|}{2004} & \multicolumn{2}{|c|}{2014} & \multirow[b]{3}{*}{$P$} \\
\hline & Low input & High input & Low input & High input & \\
\hline & \multicolumn{4}{|c|}{$\left(\mathrm{mg} \cdot \mathrm{kg}^{-1}\right)^{\mathrm{z}}$} & \\
\hline Potassium & $163.5 \mathrm{a}$ & $257.7 \mathrm{~b}$ & $190.0 \mathrm{a}$ & $370 \mathrm{c}$ & $<0.001$ \\
\hline Calcium & $1,681.8 \mathrm{a}$ & $1,968.2 \mathrm{a}$ & $1,778.9 \mathrm{a}$ & $3,446.9 \mathrm{~b}$ & $<0.001$ \\
\hline Magnesium & $83.9 \mathrm{a}$ & $161.4 \mathrm{~b}$ & $76.3 \mathrm{a}$ & $282.4 \mathrm{c}$ & $<0.001$ \\
\hline Zinc & $6.6 \mathrm{a}$ & $9.5 \mathrm{a}$ & 5.9 a & $18.3 \mathrm{~b}$ & $<0.001$ \\
\hline Iron & - & - & $7.6 \mathrm{a}$ & $8.3 \mathrm{a}$ & 0.31 \\
\hline Sodium & $3.8 \mathrm{a}$ & $5.3 \mathrm{a}$ & $7.0 \mathrm{~b}$ & $12.4 \mathrm{c}$ & 0.06 \\
\hline
\end{tabular}

${ }^{\mathrm{z}} \mathrm{l} \mathrm{mg} \cdot \mathrm{kg}^{-1}=1 \mathrm{ppm}$.

y Data analyzed with a two-way (year and treatment) analysis of variance followed by means separation (Tukey's at $\alpha=0.05$ ). Across each row entries followed by the same letter are not significantly different.

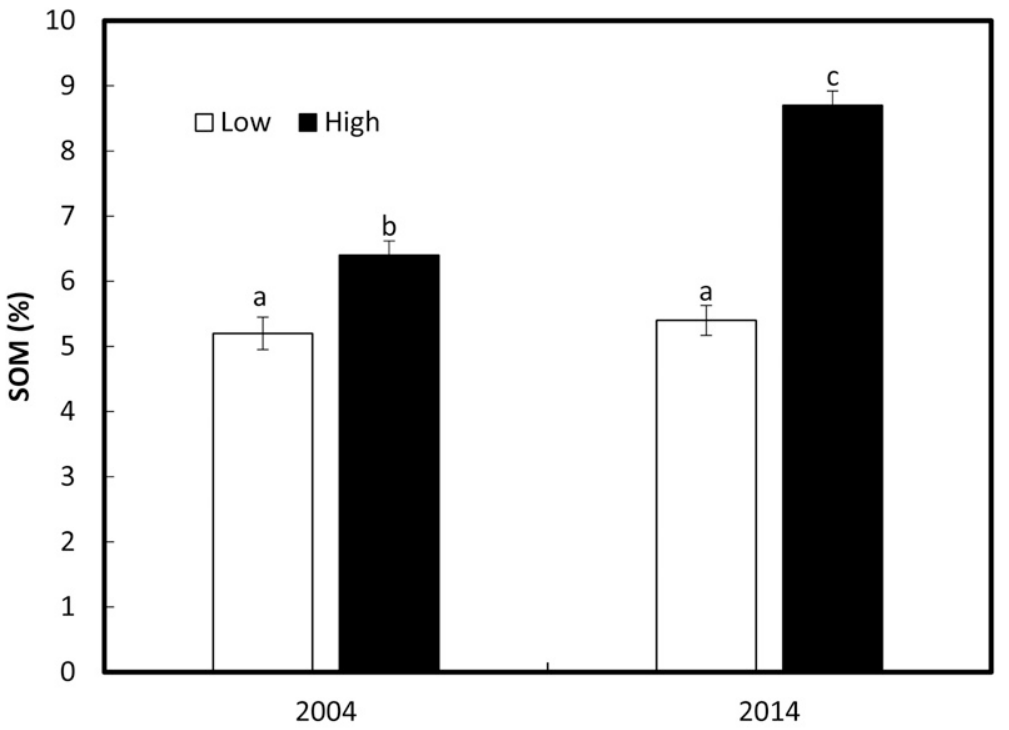

Sample year

Fig. 1. Soil organic matter [SOM (loss on ignition)] in low-input plots (yearly incorporation of green manure and mulches) vs. high-input plots [yearly incorporation of green manure and mulches and 10 tons/acre $\left(22.42 \mathrm{t} \cdot \mathrm{ha}^{-1}\right)$ of dairy manure] in 2004 and 2014. Means separation within treatment and year by Fisher's protected least significant difference $(P \leq 0.05)$. Error bars indicate SE $(n=16)$.

maintenance of high organic matter in agronomic systems several years after conversion from sod has been reported (Bowman and Anderson, 2002). Hay mulch additions during years 3 and 4 of our 4-year crop rotation (Table 2), cover crop incorporation, and routine tillage between crops to control weeds and prepare seed bed therefore resulted in limited changes in organic matter concentration over the past 16 years. Tillage has been shown to be a major contributor to the loss of organic matter in many studies (Abdollahi et al., 2014; Garcia-Franco et al., 2015). Here we show that applications of $\approx 5$ tons/acre of hay mulch during 2 of the 4 years of our rotation can offset the effect of routine tillage in organic vegetable production. A significant increase in SOM from $6.4 \%$ in 2004 to $8.7 \%$ in 2014 was observed in highinput plots (Fig. 1). Not surprisingly, bulk density was significantly lower in high-input plots than low-input plots, 1.14 and $1.22 \mathrm{~g} \cdot \mathrm{cm}^{-3}$, respectively (Fig. 2). The benefits of manure and compost addition on organic matter concentration and bulk density have been widely publicized (Abdollahi et al., 2014; Chan et al., 2011). However, annual addition of manure at relatively low application rates (10 tons/acre) in addition to the incorporation of hay mulches in our study and others shows that small incremental changes can result in significant increases in SOM even under heavy tillage (Evanylo et al., 2008).

After 15 years of management phosphorus and potassium levels are considered very high for the soils in our high-input plots (Table 4 ). Other nutrients including calcium, zinc, and copper are elevated as well when compared low-input plots, a direct result of the addition of animal manure (Table 4). Excess nutrients and phosphorus leaching are often a side effect of continuous manure or composted manure applications (Evanylo et al., 2008; Vanden Nest et al., 2014). These observations suggest that manure application made to meet nitrogen needs and improve SOM concentration should be made judiciously and balanced with other forms of fertility management such as green manure, the incorporation of mulches, and composts based on vegetation rather than livestock manures (Evanylo et al., 2008; Schmutz et al., 2007).

For the two selected years, 2004 and 2014, yearly manure application increased yields by $22 \%$ in all crops combined; however, individual crops responded quite differently. The yield was $9 \%, 25 \%, 24 \%$, and $24 \%$ higher in high-input plots than for low input for tomato, green pepper, zucchini, and green bean crops, respectively, for the two selected years under investigation. Data associated with individual years often did not show significant differences between treatments (Table 5 ). However, when the 2 years presented 
here are normalized and combined we do find significant differences (Table $5)$. When those differences in yields are translated in retail value of manure, compost application of 10 tons/acre can return from $\$ 7850 /$ acre for tomatoes to $\$ 17,760 /$ acre for zucchini (Table 5). Vegetable-cropping systems without the addition of external green waste or livestock manure are possible and profitable (Schmutz et al., 2007). However, higher intensity vegetable cropping systems will always need some external outputs (Schmutz et al., 2007). Our study shows that the cost of purchasing these external inputs can be easily justified with significantly higher yields. Other studies have shown these same benefits. The application of a single application of
$125 \mathrm{t} \cdot \mathrm{ha}^{-1}$ ( 55.8 tons/acre) of garden waste compost-similar to the combined application of 15 years of dairy manure-resulted in higher yields of a number of vegetable crops while improving soil health benefits (Chan et al., 2011). However, additional data from concurrent experiments at the WVU organic farm with differing rates of manure ( 5 to 40 tons/acre) show that higher application rates (more than 10 tons/acre of composted dairy manure) can lead to nutrient leaching and phosphorus build up in soils in less than two growing seasons (data not shown). The associated increases in yields and economic returns can therefore easily lead to the less than judicious application of composts or aged manure. Interestingly increased cost

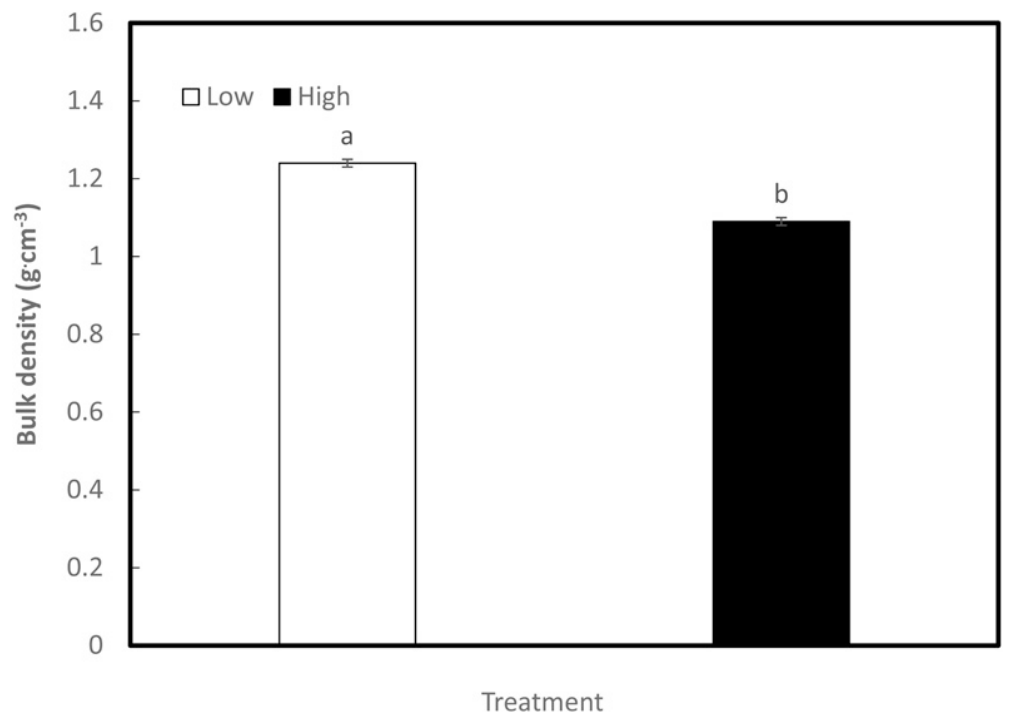

Fig. 2. Bulk density of soils in low-input plots (yearly incorporation of green manure and mulches) vs. high-input plots [yearly incorporation of green manure and mulches and 10 tons/acre $\left(22.42 \mathrm{t} \cdot \mathrm{ha}^{-1}\right)$ of dairy manure] in 2014 after 15 years of continuous management. Means separation within treatment by Fisher's protected least significant difference $(P \leq 0.05)$. Error bars indicate SE $(n=16)$; $1 \mathrm{~g} \cdot \mathrm{cm}^{-3}=62.4274 \mathrm{lb} / \mathrm{ft}^{3}$.

due to distance to the source of dairy manure may actually aid in the correct application of composts as transportation costs may reduce or limit the amount of dairy waste applied (Adhikari et al., 2005).

\section{Conclusions}

Our observations have led us to two conclusions. First, in soils with adequate levels of phosphorus and potassium, green manures, and incorporation of hay mulches can maintain yields at $80 \%$ to $92 \%$ of high-input plots even after a decade and a half of vegetable production. Soil analysis indicates that these lower yields may be mostly the result of lower nitrogen levels compared with the use of manure, as the availability of soil phosphorus, potassium, and other nutrients was adequate even in low-input plots after 15 years of production. This observation is most likely related to the relatively small amount of nutrients that are removed in the harvest of vegetables in our study. Good management of legumebased green manures with an occasional application of animal manure, animal manure based compost, or hay mulch can significantly increase crop yields while safeguarding the environment. Second, moderate amounts of partially composted dairy manure (10 tons/acre) can result in significant increases in SOM over time. Clearly, the high potential returns in increased production (Table 5) and improvements in some soil health indicators such organic matter and bulk density, may encourage over application of compost. However, the moderate applications in our experiment also lead to very high stocks of phosphorus and potassium. We suggest that nitrogen

Table 5. Yields of selected crops in low input (yearly incorporation of green manure and mulches) versus high input [yearly incorporation of green manure and mulches and 10 tons/acre $\left(22.42 \mathrm{t} \cdot \mathrm{ha}^{-1}\right)$ of dairy manure] in 2004 and 2014 with normalized (expressed as percent of average yield within a season) and combined yield data of the 2004 and 2014 growing season expressed in percent of average yields for those years. Data were analyzed with one-way analysis of variance. Price premium of compost application was calculated with estimated retail value of $\$ 3.50, \$ 2.00, \$ 3.00$, and $\$ 3.00 / 1 b$ for green bean, zucchini, tomato, and pepper, respectively and is based on the average yield of the 2004 and 2014 growing seasons. ${ }^{2}$

\begin{tabular}{|c|c|c|c|c|c|c|c|c|c|c|c|}
\hline \multirow[b]{2}{*}{ Crop } & \multicolumn{3}{|c|}{2004} & \multicolumn{3}{|c|}{2014} & \multicolumn{5}{|c|}{$2004 / 2014$ normalized and combined yield data } \\
\hline & $\begin{array}{c}\text { Low } \\
\text { input } \\
(\text { lb } / \text { acre })^{z}\end{array}$ & $\begin{array}{c}\text { High } \\
\text { input } \\
\text { (lb/acre) }\end{array}$ & $P$ & $\begin{array}{c}\text { Low } \\
\text { input } \\
\text { (lb/acre) }\end{array}$ & $\begin{array}{c}\text { High } \\
\text { input } \\
\text { (lb/acre) }\end{array}$ & $P$ & $\begin{array}{c}\text { Low } \\
\text { input } \\
(\%) \\
\end{array}$ & $\begin{array}{c}\text { High } \\
\text { input } \\
(\%)\end{array}$ & $\begin{array}{c}\text { Difference } \\
(\%)\end{array}$ & $P$ & $\begin{array}{c}\text { Premium at } \\
10 \text { tons/acre } \\
\text { compost }(\$ / \text { acre })^{x}\end{array}$ \\
\hline Bean & 17,050 & 20,085 & 0.11 & 12,360 & 17,250 & 0.22 & 88.5 & 112.0 & 23.5 & 0.05 & 11,560 \\
\hline Zucchini & 65,173 & 79,287 & 0.08 & 41,928 & 53,994 & 0.12 & 88.1 & 111.9 & 23.8 & 0.01 & 17,760 \\
\hline Tomato & 48,606 & 66,451 & 0.56 & 42,707 & 43,658 & 0.81 & 96.3 & 105.5 & 9.2 & 0.56 & 7,850 \\
\hline
\end{tabular}

${ }^{{ }^{2}} \$ 1.00 / \mathrm{lb}=\$ 2.2046 / \mathrm{kg} ; \mathrm{l} \mathrm{lb} /$ acre $=1.1209 \mathrm{~kg} \cdot \mathrm{ha}^{-1} ; \$ 1 /$ acre $=\$ 2.471 \mathrm{l} / \mathrm{ha}$. 
levels should not be managed with animal manures or animal manurebased compost, and should only be applied when phosphorus or potassium limit production.

\section{Literature cited}

Abdollahi, L., L.J. Munkholm, S. Elmholt, and P. Schjinning. 2014. The effects of organic matter application and intensive tillage and traffic on soil structure formation and stability. Soil Tillage Res. 136:2837.

Adhikari, M., K.P. Paudel, N.R. Martin, and W.M. Gauthier. 2005. Economics of dairy waste use as fertilizer in central Texas. Waste Mgt. 10:1067-1074.

Arthur, E., E. De Rocker, J. Vermang, and W.M. Cornelis. 2011. Amending a loamy sand with three compost types: Impact on soil quality. Soil Use Mgt. 27:116-123.

Bowman, R.A. and R.L. Anderson. 2002. Conservation reserve program: Effects on soil carbon and preservation when converting back to cropland in northeastern Colorado. J. Soil Water Conserv. 57:121126.

Chan, K.Y., L. Orr, D. Fahey, and C.G. Dorahy. 2011. Agronomic and economic benefits of garden organics compost in vegetable production. Compost Sci. Util. 19:97-104.

Chang, E., R. Chung, and Y. Tsai. 2007. Effect of different application rates of organic fertilizer on soil enzyme activity and microbial population. Soil Sci. Plant Nutr. 53:132-140.

Darby, H.M., R.P. Dick, and A.G. Stone. 2006. Compost- and manure-mediated impacts on soil-borne pathogens and soil quality. Soil Sci. Soc. Amer. J. 70:347-358.

Delate, K., A. McKern, and C. Cambaradella. 2008. Effects of organic fertilization and cover crops on an organic pepper system. HortTechnology 18:215-226.

Delate, K., C. Cambardella, C. Chase, and R. Turnbull. 2015. A review of long-term organic comparison trials in the U.S. Sustain. Agr. Res. 4:5-14.

Endelman, J.B., D.J. Hole, J.R. Reeve, and R. Jennifer. 2010. Economically optimal compost rates for organic crop production. Agron. J. 102:1283-1289.

Evanylo, G., M. Brosius, K. Haering, D. Starner, C. Sherony, and J. Spargo. 2008. Soil and water environmental effects of fertilizer-, manure-, and compost-based fertility practices in an organic vegetable cropping system. Agr. Ecosyst. Environ. 127:50-58.
Garcia, A.M., C.A. Rotz, L.S. Saporito, T.L. Veith, and P.J.A. Kleinman. 2008. Assessing manure management strategies through small-plot research and whole farm modeling. J. Soil Water Conserv. 63:204-211.

Garcia-Franco, N., J. Albaladejo, M. Almagro, and M. Martinez-Mena. 2015. Beneficial effects of reduced tillage and green manure on soil aggregation and stabilization of organic carbon in a Mediterranean agroecosystem. Soil Tillage Res. 153:66-75.

Gilman, S. and J. Langer. 2011. Organic soil fertility and weed management. Chelsea Green, White River Junction, VT.

Gunter, C.C. 2010. Cover crops in processing tomato, snap beans and sweetcorn production yield and harvest quality. Acta Hort. 852:233-238.

Herencia, J.F., C. Maqueda, J. Dorado, R. Antonio, and P.A. Garcia-Galavis. 2011. Comparison of nutritional quality of the crops grown in an organic and conventional fertilized soil. Scientia Hort. 129:882-888.

Horneck, S.B. 1992. Factors affecting the nutritional quality of crops. Amer. J. Altern. Agr. 7:63-68.

Idowu, O.J., R.R. Schindelbeck, B.N. Moebius-Clune, B.K. Gugino, H.M. van Es, G.S. Abawi, and D.W. Wolfe. 2009. Use of an integrative soil health test for evaluation of soil management impacts. Renew. Agr. Food Syst. 24:214-224.

Knight, A., M.D. Kleinhenz, P.S. Grewal, K.R. Islam, Z. Cheng, and S.S. Grewal. 2013. Soil health as a predictor of lettuce productivity and quality: A case study of urban vacant lots. Urban Ecosyst. 16:637-656.

Lee, J. 2010. Effect of application methods of organic fertilizer on growth, soil chemical properties and microbial densities in organic bulb onion production. Scientia Hort. 124:299-305.

Mitchell, A.E., D.E. Bryant, R.F. Denison, S. Kaffka, Y.J. Hong, and D.M. Barrett. 2007. Ten year comparison of organic and conventional crop management practices on the content of flavonoids in tomatoes. J. Agr. Food Chem. 55:61546159.

Ndiaye, E.L., R.P. Dick, D. McGrath, and J.M. Sandeno. 2000. Integrative biological indicators for detecting change in soil quality. Amer. J. Altern. Agr. 15:26-36.

Ozores-Hampton, M., P.A. Stansly, and R. McSorley. 2012. Effects of long-term organic amendments and soil sanitation on weed and nematode populations in pepper and watermelon crops in Florida. Crop Prot. 41:106-112.

Pattison, A.B., J.A. Cobon, V. Rasiah, R. Mayer, L.M. Gulino, K.A. Badcock, P.W. Moody, J.A. Armour, and L.J. Smith. 2008. Development of key soil health indicators for the Australian banana industry. Appl. Soil Ecol. 40:155-164.

Pritchett, K., C.G. Cogger, and A.C. Kennedy. 2011. Management effects on soil quality in organic vegetable systems in western Washington. Soil Sci. Soc. Amer. J. 75:605-615.

Schmutz, U., C. Firth, and F. Rayns. 2007. Balancing fertility management and economics in organic field vegetable rotations. J. Sci. Food Agr. 87:2791-2793.

Srivastava, R., A.K. Sharma, and D. Roseti. 2007. The evaluation of microbial diversity in a vegetable based cropping system under organic practices. Appl. Soil Ecol. 36:116-123.

Swenson, J.A., S.K. Chong, and S.A. Walters. 2004. Influence of tillage and mulching systems on soil water and tomato fruit yield and quality. J. Veg. Crop Production 10:81-95.

U.S. Department of Agriculture (USDA). 1982. Soil survey of Marion and Monongalia counties, West Virginia. Soil Conservation Serv. U.S. Dept. Agr., Washington, DC.

U.S. Department of Agriculture (USDA). 2002. National organic program. 21 Sept. 2016. <https://www.ams.usda.gov/ about-ams/programs-offices/nationalorganic-program $>$.

U.S. Department of Agriculture (USDA). 2015. 2012 Census of Agriculture highlights: 2014 Organic survey. 21 Sept. 2016. <https://www.agcensus.usda. gov/Publications/2012/Online_ Resources/Highlights/Organics/2014_ Organic_Survey_Highlights.pdf $>$.

Vanden Nest, T., B. Vandecasteele, G. Ruysschaert, M. Cougnon, R. Merckx, and D. Reheul. 2014. Effects of organic and mineral fertilizers on soil $\mathrm{P}$ and $\mathrm{C}$ levels, crop yield and $\mathrm{P}$ leaching in a longterm trial on a silt loam soil. Agr. Ecosyst. Environ. 197:309-317.

Waldrip, H.M., T.S. Griffin, and Z. He. 2012. Effects of organic dairy manure on soil phosphatase activity, available soil phosphorus, and growth of sorghumsudangrass. Soil Sci. 177:629-637.

Wu, Z. and J.M. Powell. 2007. Dairy manure type, application rate, and frequency impact plants and soils. Soil Sci. Soc. Amer. J. 71:1306-1313. 